\title{
The Trp64Arg Mutation of the $\beta 3$ Adrenergic Receptor Gene Has no Effect on Obesity Phenotypes in the Québec Family Study and Swedish Obese Subjects Cohorts
}

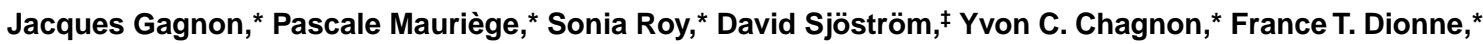 \\ Jean-Michel Oppert, ${ }^{*}$ Louis Pérusse, ${ }^{*}$ Lars Sjöström, ${ }^{\ddagger}$ and Claude Bouchard ${ }^{\star}$ \\ *Physical Activity Sciences Laboratory, Laval University, Québec, Canada; and ${ }^{\ddagger}$ Medical Department, University of Göteborg, \\ Sahlgrenska Hospital, Göteborg, Sweden
}

\begin{abstract}
The $\beta$ adrenergic system plays a key role in regulating energy balance through the stimulation of both thermogenesis and lipid mobilization in brown and white adipose tissues in human and various animal models. Recent studies have suggested that a missense Trp64Arg mutation in the $\beta 3$ adrenergic receptor (ADRB3) gene was involved in obesity and insulin resistance. We have investigated the effect of this mutation on obesity-related phenotypes in two cohorts: the Québec Family Study (QFS) and the Swedish Obese Subjects (SOS). In QFS, no association was found between this mutation and body mass index (BMI), body fat including abdominal visceral fat, resting metabolic rate, various diabetes and cardiovascular risk factors, and changes in body weight and body fat over a 12 -yr period. With the exception of RMR $(P=0.04)$, no evidence of linkage was detected between the mutation and phenotypes of QFS based on sib-pair data. In SOS, the frequency of the Trp64Arg allele was not significantly different between nonobese and obese female subjects and no association was found between the mutation and body weight gain over time. These findings do not support the view that there is an association between the Trp64Arg mutation in the ADRB3 gene and obesity. (J. Clin. Invest. 1996. 98:2086-2093.) Key words: mutation • diabetes $\bullet$ linkage $\bullet$ body fat $\bullet$ visceral fat
\end{abstract}

\section{Introduction}

There is strong evidence suggesting that human obesity has both genetic and environmental determinants (1). It is also established that an obese state results from an imbalance between caloric intake and energy expenditure, and that a low resting metabolic rate could be predictive of weight gain (2). In this regard, the adrenergic system plays a key role in regulating energy balance through the stimulation of both thermogenesis and lipid mobilization in brown and white adipose tissues in humans and various animal models $(3,4)$. Although these ef-

Address correspondence to Dr. Claude Bouchard, Physical Activity Sciences Laboratory, Laval University, PEPS-2152, Ste-Foy, Québec, G1K 7P4, Canada. Phone: 418-656-5174; FAX: 418-656-3044.

Received for publication 21 June 1996 and accepted in revised form 28 August 1996.

J. Clin. Invest.

(C) The American Society for Clinical Investigation, Inc. 0021-9738/96/11/2086/08 \$2.00

Volume 98, Number 9, November 1996, 2086-2093 fects have been mainly attributed to $\beta 1$ and $\beta 2$ adrenergic receptors, the relative contribution in catecholamine action of a third $\beta$ adrenoceptor subtype, which has been cloned in man (5-7), bovines (8), and rodents (9-11) should also be considered $(3,4)$.

Numerous pharmacological studies performed with highly selective $\beta 3$ adrenergic agonists considered as potent antiobesity and antidiabetic drugs (4) have confirmed the involvement of $\beta 3$ adrenoceptors in both adipocyte lipolysis and thermogenic activity in various laboratory animals $(3,12)$. In contrast, although $\beta 3$ adrenergic receptors were clearly expressed in a variety of human fat depots (13), their physiological importance in man remains controversial (14). In vitro studies have revealed little or no lipolytic response to $\beta 3$ adrenoceptor agents in either isolated subcutaneous fat cells (15-17) or adipose tissue fragments (18). However, the existence of functional $\beta 3$ adrenoceptors assessed by in vitro assays has already been demonstrated in omental adipocytes $(19,20)$ whereas the lack or the presence of only a weak proportion of this adrenoceptor subtype in intraabdominal fat cells has been reported by others $(21,22)$. On the other hand, in vivo studies using the microdialysis technique have revealed a weaker role of $\beta 3$, compared to $\beta 1$, and $\beta 2$ adrenergic receptors, in the control of both lipolysis and nutritive blood flow in human subcutaneous adipose tissue $(23,24)$. Despite these conflicting results which seem to be mainly due to the selectivity of the $\beta 3$ adrenergic compounds tested and the methodology used, an increased $\beta 3$ adrenoceptor component in visceral adipose tissue could be responsible for the enhanced delivery of free fatty acids into the portal vein, a phenomenon which may contribute to the development of the metabolic disturbances generally observed in abdominal obesity $(20,25)$. An abnormality in the $\beta 3$ adrenergic receptor (ADRB3) ${ }^{1}$ could therefore potentially represent a link between abdominal obesity and insulin resistance.

A missense mutation in codon 64 of the ADRB3 gene that results in the replacement of tryptophan by arginine in the first intracellular loop of the receptor protein, has recently been reported in various ethnic groups including Pima Indians, known for their high prevalence of obesity and noninsulin dependent diabetes mellitus (NIDDM) (26), Finns (27), French Caucasians (28) and Japanese (29). In addition, the Tryptophan 64 arginine (Trp64Arg) mutation has been associated with an early onset of NIDDM (26) and an increased weight gain with age in morbidly obese patients (28). A defect in the $\beta 3$ adren-

1. Abbreviations used in this paper: ADRB3, $\beta 3$ adrenergic receptor; BMI, body mass index; NIDDM, noninsulin dependent diabetes mellitus; QFS, Québec Family Study; RMR, resting metabolic rate; SOS, Swedish Obese Subjects; Trp64Arg, tryptophan 64 arginine. 


\begin{tabular}{|c|c|c|c|c|c|c|}
\hline \multirow[b]{2}{*}{ Variables } & \multicolumn{3}{|c|}{ Men } & \multicolumn{3}{|c|}{ Women } \\
\hline & $n$ & Mean \pm SD & Range & $n$ & Mean \pm SD & Range \\
\hline Age (yrs) & 119 & $55.1 \pm 6.6$ & $40-73$ & 123 & $52.5 \pm 5.7$ & $36-68$ \\
\hline Body weight (kg) & 117 & $81.4 \pm 15.2$ & $51-128$ & 121 & $67.5 \pm 16.4$ & $43-150$ \\
\hline Body mass index $\left(\mathrm{kg} / \mathrm{m}^{2}\right)$ & 117 & $28.0 \pm 5.0$ & $19-47$ & 121 & $26.7 \pm 6.3$ & $19-56$ \\
\hline Waist circumference $(\mathrm{cm})$ & 117 & $97.7 \pm 12.8$ & $70-134$ & 120 & $83.3 \pm 15.3$ & $63-139$ \\
\hline Maximal weight $(\mathrm{kg})$ & 116 & $85 \pm 17$ & $54-136$ & 121 & $71 \pm 19$ & $49-153$ \\
\hline Body fat (\%) & 102 & $27.4 \pm 6.6$ & $8-43$ & 94 & $37.2 \pm 7.5$ & $19-54$ \\
\hline Fat mass $(\mathrm{kg})$ & 102 & $23 \pm 9$ & $5-50$ & 94 & $25 \pm 9$ & $10-51$ \\
\hline Fat free mass $(\mathrm{kg})$ & 102 & $58 \pm 7$ & $44-80$ & 94 & $41 \pm 5$ & $32-57$ \\
\hline Subcutaneous fat (mm) & 117 & $100 \pm 42$ & $24-287$ & 117 & $140 \pm 52$ & $48-314$ \\
\hline Abdominal total fat area $\left(\mathrm{cm}^{2}\right)$ & 87 & $399 \pm 166$ & $46-853$ & 87 & $448 \pm 183$ & $152-990$ \\
\hline Abdominal visceral fat area $\left(\mathrm{cm}^{2}\right)$ & 87 & $165 \pm 78$ & $30-443$ & 87 & $125 \pm 68$ & $34-381$ \\
\hline Abdominal subcutaneous fat area $\left(\mathrm{cm}^{2}\right)$ & 87 & $234 \pm 108$ & $16-610$ & 87 & $323 \pm 132$ & $112-712$ \\
\hline Resting metabolic rate (kcal/min) & 111 & $1.130 \pm 0.156$ & $0.79-1.76$ & 113 & $0.888 \pm 0.127$ & $0.68-1.37$ \\
\hline
\end{tabular}

Subcutaneous fat was estimated by sum of six skinfolds. Abdominal fat areas were measured using L4-L5 CT scanning. Values are means \pm SD.

ergic receptor could be of clinical importance in the pathophysiology of obesity because it could lead to alterations in signal transduction and regulatory mechanisms and result in decreased adipose tissue lipolysis and resting metabolic rate as well as an exaggerated body fat accretion. It has recently been suggested that the Trp64Arg allele of the ADRB3 gene could be predictive of some difficulties in losing weight in obese Japanese women (30). Therefore, the aims of the present study were: $(a)$ to investigate the prevalence of the Trp64Arg $\beta 3$ adrenergic receptor mutation in two different cohorts: the Québec Family Study (QFS), and the Swedish Obese Subjects (SOS); and $(b)$ to investigate the relationships between the Trp64Arg mutation in the ADRB3 receptor gene and obesity-related phenotypes using these data bases.

\section{Methods}

\section{Description of the cohorts}

The first cohort was that of the QFS (31). It consists of 1,628 individuals from French-Canadian families living in and around Québec City and recruited through the media during the years 1978-1981 (Phase 1). Each subject was examined by a physician in order to exclude individuals with metabolic disorders such as diabetes and dyslipidemias. The subjects gave their written consent to participate in the study which received the approval of the Laval University Medical Ethics Committee. Between 1989 and 1993 (Phase 2), a subset of these QFS families was remeasured and permanent lymphoblastoid cell lines were established for each individual and used to extract DNA.

From Phase 2 of QFS, we studied 552 subjects, $18 \mathrm{yr}$ of age and older, from 126 nuclear families. DNA was available from 242 biologically unrelated adults from the parental generation (119 men whose age ranged between 40 and $73 \mathrm{yr}$, and 123 women who were from 36 to $68 \mathrm{yr}$ ). Sib-pair linkage analyses were also performed and the number of pairs ranged from 142 to 255 depending on the phenotype considered. The phenotypic characteristics of the unrelated adults are shown in Table I. Changes in body mass and body fat phenotypes over a 12-yr period are presented in Table II.

The second sample comes from the SOS $(32,33)$. Data presented in this paper are based on a subsample on 385 female obese subjects (37-60-yr-old) from SOS, whose body mass index (BMI) was greater than $33 \mathrm{~kg} / \mathrm{m}^{2}$, examined in both urban and rural counties in Sweden. A description of the physical characteristics of this cohort sample is given in Table III. An age-matched (48.4 vs. $47.8 \mathrm{yr}$ ) nonobese subset of 83 Swedish women, with a BMI less than $27 \mathrm{~kg} / \mathrm{m}^{2}$, served as a control group. DNA was extracted from total blood for these subjects.

\section{Obesity-related phenotypes}

QFS Cohort. BMI was calculated as body weight $(\mathrm{kg})$ divided by squared height $\left(\mathrm{m}^{2}\right)$. Maximal weight over the last $10 \mathrm{yr}$ was assessed by means of a questionnaire. Body density was determined by the hy-

Table II. Characteristics of the Québec Family Study Cohort-Changes ( $\triangle$ ) between 1978-1981 and 1989-1993

\begin{tabular}{|c|c|c|c|c|c|c|}
\hline \multirow[b]{2}{*}{ Variables } & \multicolumn{3}{|c|}{ Men } & \multicolumn{3}{|c|}{ Women } \\
\hline & $n$ & Mean \pm SD & Range & $n$ & Mean \pm SD & Range \\
\hline$\triangle$ Body weight $(\mathrm{kg})$ & 92 & $2.3 \pm 5.8$ & -12.2 to +20.7 & 95 & $4.5 \pm 5.6$ & -7.7 to +26.1 \\
\hline$\triangle$ Body mass index $\left(\mathrm{kg} / \mathrm{m}^{2}\right)$ & 92 & $1.1 \pm 1.9$ & -3.5 to +7.4 & 95 & $2.1 \pm 2.3$ & -2.4 to +11.5 \\
\hline$\triangle$ Subcutaneous fat $(\mathrm{mm})$ & 92 & $14.9 \pm 20.1$ & -36.1 to +79.8 & 95 & $34.2 \pm 28.7$ & -24 to +124 \\
\hline$\triangle$ Body fat $(\%)$ & 46 & $5.3 \pm 5.0$ & -2.6 to +24.2 & 44 & $6.7 \pm 5.6$ & -3.1 to +20.6 \\
\hline$\triangle$ Fat mass $(\mathrm{kg})$ & 46 & $4.5 \pm 4.3$ & -2.2 to +20.6 & 44 & $5.6 \pm 4.4$ & -2.1 to +14.9 \\
\hline$\triangle$ Fat free mass $(\mathrm{kg})$ & 46 & $-2.3 \pm 3.4$ & -11.7 to +6.0 & 44 & $-0.9 \pm 3.6$ & -12.9 to +5.5 \\
\hline
\end{tabular}


Table III. Characteristics of the Swedish Obese Women Cohort

\begin{tabular}{|c|c|c|c|c|c|c|}
\hline \multirow[b]{2}{*}{ Variables } & \multicolumn{3}{|c|}{ Control } & \multicolumn{3}{|c|}{ Obese } \\
\hline & $n$ & Mean \pm SD & Range & $n$ & Mean \pm SD & Range \\
\hline Age (yr) & 83 & $48.4 \pm 7.1$ & $37-60$ & 385 & $47.8 \pm 6.0$ & $37-58$ \\
\hline Body weight (kg) & 83 & $62.4 \pm 6.4$ & $49-76$ & 385 & $110.5 \pm 12.3^{*}$ & $82-158$ \\
\hline $\begin{array}{l}\text { Body mass index } \\
\left(\mathrm{kg} / \mathrm{m}^{2}\right)\end{array}$ & 83 & $22.7 \pm 2$ & $18-27$ & 385 & $40.8 \pm 4 *$ & $33-58$ \\
\hline
\end{tabular}

$* P<0.01$; significant difference between control and obese subjects at $P<0.01$.

drostatic weighing technique (34) and pulmonary residual volume was measured using the helium dilution method (35). Percent body fat was derived from body density using the Siri equation (36). Fat mass was determined by multiplying percent body fat by body weight. Waist circumference was measured at the smallest circumference above the level of the iliac crest. Skinfolds were measured on the left side of the body using a Harpenden skinfold caliper and following the procedures recommended at the Airlie Conference (37). The sum of six skinfolds measurements (biceps, triceps, medial calf, subscapular, suprailiac, and abdominal) was considered as an indicator of total subcutaneous fat. As body fat measurements were obtained in 19781981 and in 1989-1993, changes over the 12-yr period were also considered.

Total abdominal and visceral fat areas were obtained only during Phase 2 (1989-1993) using computerized tomography which was performed on a scanner (model Somatom DRH; Siemens, Erlangen, Germany) as previously described (38). The measurement of resting metabolic rate (RMR) was performed in Phase 2 as previously described (39). RMR was assessed in the morning after a 12 -h fast by in- direct calorimetry with a ventilated hood. The Weir formula was used to calculate energy expenditure and values were expressed in $\mathrm{kcal} /$ min (40). Several phenotypes pertaining to cardiovascular and diabetes risk factors are also considered in this paper. Resting blood pressure was measured in the morning, after the RMR assessment, on subjects who were in a fasted state and free of caffeine and tobacco products. A 75-g oral glucose tolerance test (OGTT) was performed in the morning after a 12-h fast. Blood samples were collected at 15min intervals during the first hour following the glucose ingestion and every $30 \mathrm{~min}$ for the subsequent $2 \mathrm{~h}$ as previously described (41). Plasma glucose was enzymatically measured (42), whereas plasma insulin was measured by radioimmunoassay with polyethylene glycol separation (43). Glucose and insulin total areas under the curve during the OGTT were determined by the trapezoid method.

SOS cohort. BMI was available on the SOS and control female subjects. Before undergoing a health examination, all subjects completed a series of questionnaires on current and past health status, including various aspects of weight history such as information on recalled weights at ages $20,30,40,45,50,55$ as appropriate, recent weight changes in the previous 6,12 , and $24 \mathrm{mo}$, and the age at which obesity became "a problem" (33).

\section{Genetic analyses}

Genomic DNA was isolated from either whole blood samples (SOS cohort) or from permanent lymphoblastoid cell lines (44; QFS cohort), by proteinase $\mathrm{K}$ and the phenol/chloroform extraction procedure followed by dialysis. The $\mathrm{T}$ to $\mathrm{C}$ transversion at codon 64 generates a new MspI restriction site. Specific primers were defined to cover this MspI restriction site (Figs. $1 A$ and $B$ ). Each $30 \mu l$ reaction contained $100 \mathrm{ng}$ of genomic DNA, $250 \mathrm{ng}$ of each primer, $1.5 \mathrm{mM}$ $\mathrm{MgCl}_{2}, 50 \mathrm{mM} \mathrm{KCl}, 10 \mathrm{mM}$ Tris/ $\mathrm{HCl} \mathrm{pH} 8.3,0.001 \%$ gelatin, $200 \mu \mathrm{M}$ dNTPs, 1.5 unit Taq polymerase, and 10\% DMSO. The reactions were incubated at $95^{\circ} \mathrm{C}$ for $3 \mathrm{~min}, 60^{\circ} \mathrm{C}$ for $15 \mathrm{~s}, 72^{\circ} \mathrm{C}$ for $30 \mathrm{~s}$ followed by 29 cycles at $95^{\circ} \mathrm{C}$ for $15 \mathrm{~s}, 60^{\circ} \mathrm{C}$ for $15 \mathrm{~s}$, and $72^{\circ} \mathrm{C}$ for $30 \mathrm{~s}$ using a thermal cycler (model 9600; Perkin-Elmer Cetus Instruments, Branchburg, NJ). PCR reactions were directly digested by adding $15 \mathrm{U}$
A

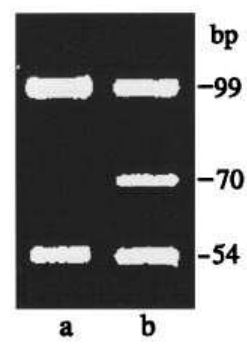

B

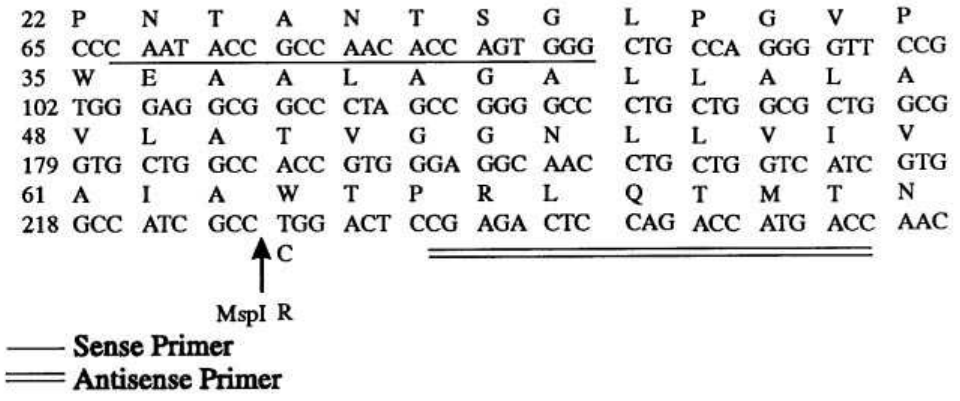

C

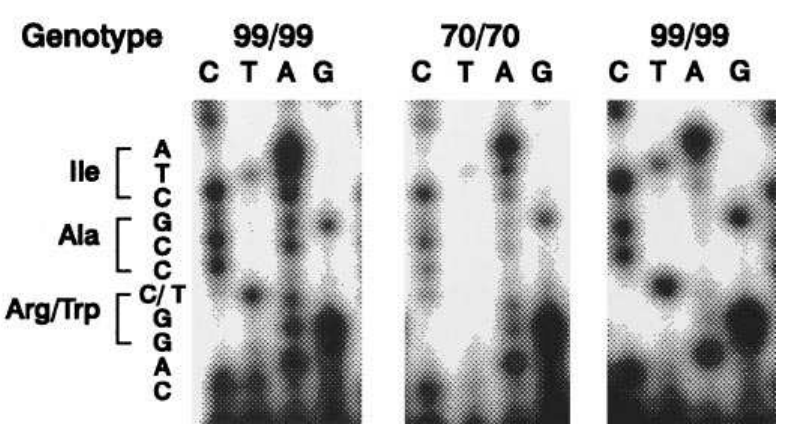

Figure 1. (A) MspI polymorphism in a $153 \mathrm{bp}$ fragment (from codon 22 to 72) for individuals having ( $a$ ) one MspI site (normal) and (b) two MspI sites (mutant). (B) Nucleotide and predicted amino acid sequences of the $153 \mathrm{bp}$ fragment obtained from GenBank (SAGE 1992) with or without the additional MspI site. Primers used for PCR are underlined (single, sense; double, antisense). Codons are numbered from the initiation site. The additional MspI restriction site when $\mathrm{T}$ is changed to $\mathrm{C}($ bold $)$ at position +189 , resulting in a change from tryptophan $(\mathrm{W})$ to arginine $(\mathrm{R} ;$ bold $)$, at codon 64 is also indicated. $(C)$ Dideoxy sequencing of Trp64Arg mutation of the human ADRB3 by direct sequencing of the PCR product. The PCR products (153 bp) from two homozygous subjects without the mutation (90/90) (left and right) or from a homozygous individual with the mutation $(70 / 70$; middle) were sequenced using the amplicycle kit (Perkin-Elmer). 


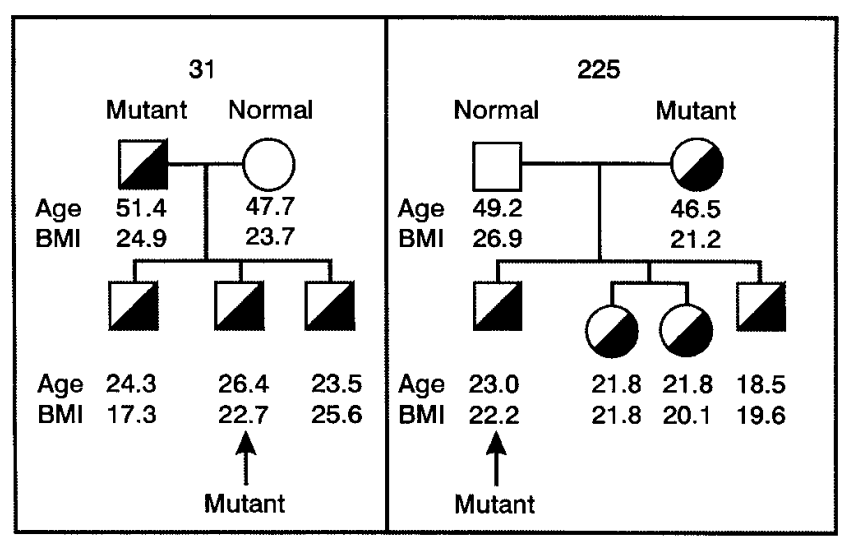

Figure 2. Pedigrees for the families 31 (left) and 225 (right) from the QFS. The first mutant (proband) detected is indicated. Age and BMI are indicated for each subject. Individuals of similar age represent identical twins.

of MspI enzyme (BRL) for $18 \mathrm{~h}$ at $37^{\circ} \mathrm{C}$ and the fragments obtained were separated on a $8 \%$ acrylamide gel and visualized under UV light after staining with ethidium bromide.

Two normal homozygotes (99/99) and the only mutant homozygote (70/70) were subjected to direct dideoxy sequence analysis of the PCR products on both strands with an Amplicycle sequencing kit (Perkin-Elmer) to confirm the $\mathrm{T}$ to $\mathrm{C}$ change at nucleotide 189 of the ADRB3 gene (Fig. $1 C$ ).

\section{Statistical analyses}

Analyses were performed with the Statistical Software Package (SAS, Cary, NC). In the QFS cohort, body weight, BMI, waist circumference, maximal weight over the past $10 \mathrm{yr}$, percent body fat, fat mass, fat free mass, sum of six skinfolds, and blood pressure were adjusted for age in each gender subsample. Abdominal fat areas were also adjusted for total fat mass, in addition to age. RMR was adjusted for age, fat mass, and fat free mass. A Student $t$ test was used to test for the difference in a quantitative phenotype between the carriers and noncarriers of the ADRB3 Trp64Arg mutation in biologically unrelated males and females from the parental generation. Comparisons of genotypes and allelic frequencies in both QFS and SOS cohorts were performed using chi-square tests.

The sib-pair linkage procedure $(45,46)$ was used to investigate the presence of linkage between the quantitative phenotypes and the Trp64Arg mutation at the ADRB3 locus. Briefly, in the presence of linkage between the marker locus and a putative gene influencing the phenotype, sibs sharing a greater proportion of alleles identical by descent at the marker locus will be more similar for the phenotype of interest. The squared sib-pair phenotypic difference is regressed on the expected proportion of marker alleles identical by descent at the locus. A one-sided $t$ test is then used to test whether the regression coefficient is different from 0 . A significant negative relationship between the squared sib-pair phenotypic difference and the marker locus is taken as evidence of linkage between the marker locus and the phenotype. The major advantage of this method is that it is nonparametric and requires no assumption about the genetic model underlying the expression of the phenotype studied. The linkage analysis was performed using the SIBPAL software program of the SAGE Statistical Package (47).

In the SOS cohort, the age and weight history variables were compared between carriers and noncarriers of the Trp64Arg mutation of the ADRB3 gene, using $t$ tests. Differences in current weight or maximal weight versus weight at $20 \mathrm{yr}$ of age were adjusted for the length of follow-up. Regression lines of weight gain over time were compared between genotypes for both the intercept and the slope. Using quintiles, analyses were also undertaken with the low and high weight gainers (first and last quintile). As subjects available for these analyses vary, the actual number of subjects for each variable is indicated in the Tables. Statistical significance was judged at $P \leq 0.05$.

\section{Results}

The nucleotide sequence of the human ADRB3 gene retrieved from GenBank (48) was used to select a fragment of $153 \mathrm{bp}$ spanning codon 22 to codon 72 within which a mutation at codon 64 has been reported (26). A 1.5-kb DNA fragment amplified by PCR and covering entirely the first exon of the ADRB3 gene did not reveal any polymorphism tested with a battery of 20 restriction enzymes (not shown). A first screen of nine lean and nine obese subjects with MspI digestion yielded two individuals displaying an additional $70 \mathrm{bp}$ fragment in contrast to the common 99- and 54-bp bands (Fig. $1 A$ ). Figs. $1 B$ and $C$ present the nucleotide sequence of the amplified 153-bp PCR fragments from two homozygotes for each of the alleles which confirm the $\mathrm{T}$ to $\mathrm{C}$ substitution at nucleotide 189 creating the MspI restriction site.

Fig. 2 illustrates the pedigree of two lean adult probands from the QFS cohort with the Trp64Arg mutation. In family 31 , the mother does not carry the Trp64Arg mutation and the father is heterozygous whereas all the offspring carry the

Table IV. Genotypic and Allelic Frequencies for an MspI Restriction Site in a 153-bp Fragment of Human ADRB3 Gene

\begin{tabular}{|c|c|c|c|c|c|}
\hline \multirow[b]{2}{*}{ Cohorts } & \multicolumn{3}{|c|}{ Genotypes } & \multicolumn{2}{|c|}{ Allelic frequency } \\
\hline & $\begin{array}{c}99 \mathrm{bp} / 99 \mathrm{bp} \\
\text { normal } \\
\text { homozygous }\end{array}$ & $\begin{array}{c}99 \mathrm{bp} / 70 \mathrm{bp} \\
\text { Trp64Arg } \\
\text { mutant heterozygous }\end{array}$ & $\begin{array}{c}70 \mathrm{bp} / 70 \mathrm{bp} \\
\text { Trp64Arg } \\
\text { mutant homozygous }\end{array}$ & $99 \mathrm{bp}$ & $70 \mathrm{bp}$ \\
\hline \multicolumn{6}{|l|}{ QFS } \\
\hline$n=242(119$ males, 123 females $)$ & 204 & 37 & 1 & 0.92 & 0.08 \\
\hline \multicolumn{6}{|l|}{ SOS Control } \\
\hline$n=83$ females & 76 & 7 & 0 & 0.96 & 0.04 \\
\hline \multicolumn{6}{|l|}{ SOS Obese } \\
\hline$n=385$ females & 333 & 51 & 1 & 0.93 & 0.07 \\
\hline
\end{tabular}

No significant difference was observed between genotypes using chi-square analyses $\left(\chi^{2}=1.6, P=0.21\right)$. QFS: Québec Family Study. SOS: Swedish Obese Subjects. 
Table V. Body Weight, Body Fat, Regional Fat Distribution and Resting Metabolic Rate from the QFS Cohort During the Period 1989-1993 in Unrelated Subjects According to Carrier Status

\begin{tabular}{|c|c|c|c|c|c|}
\hline Variables & Noncarriers & $n$ & $\begin{array}{l}\text { With Trp64Arg } \\
\text { mutation }\end{array}$ & $n$ & $P$ value \\
\hline Sex ratio (male/female) & $98 / 102$ & 200 & $19 / 19$ & 38 & - \\
\hline Body weight (kg) & $74.5 \pm 17.1$ & 200 & $71.4 \pm 14.4$ & 38 & 0.2 \\
\hline Body mass index $\left(\mathrm{kg} / \mathrm{m}^{2}\right)$ & $27.6 \pm 5.7$ & 200 & $26.8 \pm 4.7$ & 38 & 0.3 \\
\hline Waist circumference $(\mathrm{cm})$ & $91.3 \pm 15.7$ & 199 & $89.0 \pm 13.7$ & 38 & 0.3 \\
\hline Maximal weight $(\mathrm{kg})$ & $79.4 \pm 18.5$ & 199 & $74.6 \pm 15.8$ & 38 & 0.1 \\
\hline Body fat (\%) & $32.2 \pm 8.4$ & 165 & $31.7 \pm 9.6$ & 31 & 0.8 \\
\hline Fat mass (kg) & $26.9 \pm 9.4$ & 165 & $26.7 \pm 8.7$ & 31 & 0.9 \\
\hline Fat free mass (kg) & $51.1 \pm 10.8$ & 165 & $51.0 \pm 10.5$ & 31 & 0.9 \\
\hline Subcutaneous fat (mm) & $121.0 \pm 50.9$ & 196 & $114.4 \pm 42.2$ & 38 & 0.4 \\
\hline Abdominal total fat $\left(\mathrm{cm}^{2}\right)$ & $414 \pm 67$ & 130 & $433 \pm 73$ & 23 & 0.3 \\
\hline Abdominal visceral fat $\left(\mathrm{cm}^{2}\right)$ & $143 \pm 50$ & 130 & $150 \pm 51$ & 23 & 0.5 \\
\hline Abdominal subcutaneous fat $\left(\mathrm{cm}^{2}\right)$ & $271 \pm 66$ & 130 & $282 \pm 69$ & 23 & 0.4 \\
\hline $\operatorname{RMR}(\mathrm{kcal} / \mathrm{min})$ & $1.019 \pm 0.148$ & 164 & $1.000 \pm 0.150$ & 31 & 0.5 \\
\hline
\end{tabular}

Mean \pm SD. Associations with Trp64Arg mutation were assessed using $t$ tests. Body weight, BMI, percent body fat, fat mass, fat free mass, and subcutaneous fat were adjusted for age. Abdominal total, visceral, and subcutaneous fat areas were adjusted for age and fat mass. Resting metabolic rate (RMR) was adjusted for age, fat mass, and fat free mass.

Trp64Arg mutation. In family 225, the father does not carry the mutation and the mother is heterozygous. Three of four offspring as well as monozygotic twins carry the Trp64Arg mutation. This clearly demonstrates the Mendelian inheritance of this mutation. Interestingly, none of the subjects in these two families were classified as obese, as all BMIs were lower than $26 \mathrm{~kg} / \mathrm{m}^{2}$.

In the QFS cohort, allelic frequencies for the carriers and noncarriers of the Trp64Arg mutation of ADRB3 were 0.92 and 0.08 , respectively. The three genotypes (normal homozygous, mutant heterozygous, and mutant homozygous) were observed (Table IV). In the SOS cohort, similar relative allelic frequencies were observed. However, there was no difference in the allelic frequencies of control versus SOS female obese subjects (Table IV). Genotype frequencies were all in HardyWeinberg equilibrium.

Association studies. When unrelated subjects from the parental generation of the QFS cohort were studied, no difference was found in the genotype distribution between genders. Moreover, as no significant genotype-gender interaction was observed for the different phenotypic variables tested (not shown), analyses were performed on both men and women pooled together. Cross-sectional analyses using data from QFS Phase 2 did not reveal any difference in the various anthropometric and regional fat distribution indicators (including total, visceral, and subcutaneous abdominal fat areas) as well as in RMR, between carriers vs. noncarriers of the Trp64Arg mutation (Table V). In addition, carriers and noncarriers of the Trp64Arg mutation displayed similar glucose, insulin, and resting blood pressure values (Table VI). In addition, the absolute changes in body weight, BMI, subcutaneous fat, percent body fat, fat mass and fat free mass over the 12-yr period were not different between both genotypes (Table VII).

In the SOS cohort of obese women, the current age, BMI, waist circumference, and age of onset of weight problem were similar among carriers and noncarriers of the Trp64Arg mutation. There was no difference for indicators of weight history and for the weight gain, i.e., current weight minus weight at 20 yr-old, even after adjustment for difference in the duration of the follow-up period (Table VIII). During the periods 20-30,

Table VI. Diabetes and Cardiovascular Risk Factors from the QFS Cohort during the Period 1989-1993 in Unrelated Subjects According to the Carrier Status

\begin{tabular}{lcccc}
\hline \multicolumn{1}{c}{ Variables } & Noncarriers & $n$ & With Tr64Arg & \\
mutation & $P$ value \\
\hline Fasting glucose $(\mathrm{mM})$ & $5.5 \pm 1.8$ & 202 & $5.2 \pm 1.0$ & 0.30 \\
Fasting insulin $(\mathrm{pM})$ & $63.5 \pm 40.8$ & 149 & $76.0 \pm 43.2$ & 37 \\
Glucose area $\left(10^{-3} \mathrm{mM} / \mathrm{min}\right)$ & $1.33 \pm 0.34$ & 150 & $1.28 \pm 0.28$ & 25 \\
Insulin area $\left(10^{-3} \mathrm{pM} / \mathrm{min}\right)$ & $70.54 \pm 38.80$ & 148 & $85.85 \pm 56.98$ & 26 \\
Systolic blood pressure $(\mathrm{mmHg})$ & $131 \pm 16$ & 200 & $127 \pm 14$ & 26 \\
Diastolic blood pressure $(\mathrm{mmHg})$ & $76 \pm 8$ & 200 & $79 \pm 9$ & 38 \\
\end{tabular}

Mean \pm SD. Associations with Trp64Arg mutation were assessed using $t$ tests. Fasting plasma glucose and insulin levels, glucose and insulin areas, and systolic and diastolic blood pressures were all adjusted for age. 
Table VII. Changes $(\triangle)$ in Adiposity Indicators Over a 12-yr Period in the QFS Cohort for Unrelated Subjects According to Carrier Status

\begin{tabular}{lccccc}
\hline \multicolumn{1}{c}{ Variables } & Noncarriers & $n$ & With Trp64Arg & & \\
& mutation & $n$ & $P$ value \\
\hline$\triangle$ Body weight $(\mathrm{kg})$ & $3.4 \pm 6.0$ & 156 & $3.3 \pm 4.8$ & 31 & 0.88 \\
$\triangle$ Body mass index $\left(\mathrm{kg} / \mathrm{m}^{2}\right)$ & $1.6 \pm 2.2$ & 156 & $1.5 \pm 1.9$ & 31 & 0.77 \\
$\triangle$ Subcutaneous fat $(\mathrm{mm})$ & $25.6 \pm 27.4$ & 156 & $20.5 \pm 22.4$ & 31 & 0.50 \\
$\triangle$ Body fat $(\%)$ & $5.8 \pm 5.0$ & 71 & $6.4 \pm 6.6$ & 19 & 0.75 \\
$\triangle$ Fat free mass $(\mathrm{kg})$ & $-1.5 \pm 3.6$ & 71 & $-2.2 \pm 3.6$ & 19 & 0.43 \\
$\triangle$ Fat mass $(\mathrm{kg})$ & $5.0 \pm 4.1$ & 71 & $5.2 \pm 5.2$ & 19 & 0.86 \\
& & & & &
\end{tabular}

Mean \pm SD. Associations with Trp64Arg mutation were assessed using $t$ tests. Changes in body weight, body mass index, subcutaneous fat, percent body fat, fat free mass, and fat mass were adjusted for age at the beginning of the follow-up period.

30-40, 40-50, and 50-55 yr, the average rate of reported weight gain (about $1 \mathrm{~kg} / \mathrm{yr}$ ) was similar in the SOS subjects and controls. The intercept and the slope of the regression line were also similar in the two groups as shown in Fig. 3.

Moreover, after division of the cohort in quintiles of current weight minus weight at $20 \mathrm{yr}$, there was no significant difference in the frequency of the Trp64Arg mutation between the five groups (chi-square $=8.00, P=0.43$ ) or between the high $(60 \pm 8 \mathrm{~kg})$ and low weight gainers $(18 \pm 10 \mathrm{~kg})$ (Fig. 4).

Linkage study. Results from the sib-pair linkage analysis in the QFS are shown in Table IX. No significant linkage was found for the various anthropometric and fat distribution phenotypes ( $P$ values ranging from 0.21 to 0.81 ). A possible exception was a weak linkage $(P=0.04)$ with resting metabolic rate.

\section{Discussion}

We have described a MspI restriction site in the human $\beta 3$ adrenergic receptor gene. This particular point mutation was first documented in Pima Indians (26) and recently fully described in other populations (26-29). It has already been demon-
SOS FEMALE WEIGHT GAIN OVER TIME

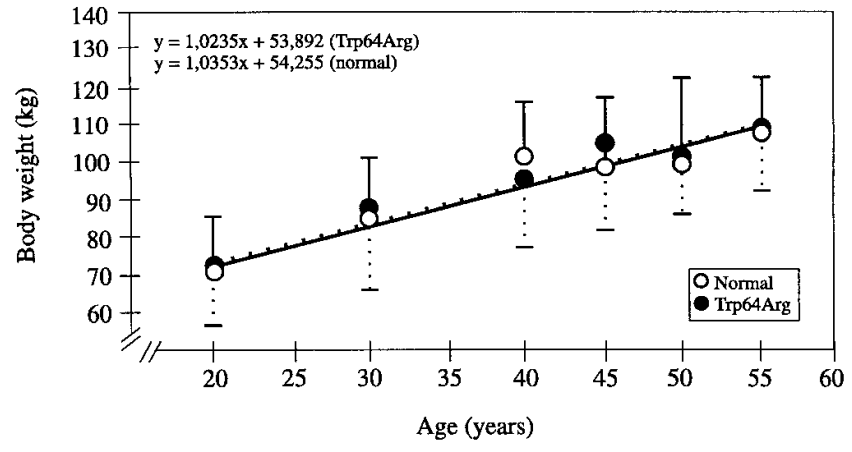

Figure 3. Weight gain over time in the SOS cohort by carrier status (open circles, noncarriers; closed circles, Trp64Arg mutant carriers). Data points are means $\pm \mathrm{SD}$. The regression line is also indicated for both groups. Comparisons of both intercept and slope are not significant.

strated that the Trp64Arg mutation abolished a recognition site for the endonuclease BstN1 (CC/WGG) (26-29). As the Trp64Arg mutation creates a new MspI site (C/CGG), the RFLP detection is straightforward. The Trp64Arg mutation has been studied in many populations such as Pima Indians, and Mexican, black, and white Americans (26), normal nondiabetic and diabetic Finnish subjects (27), French morbidly obese people (28), as well as Japanese subjects (29). In the present study, we document the allelic frequencies for two other Caucasian populations: 56French Canadians and Swedes. It should be noted that the allelic frequency of the Trp64Arg mutation among these populations is quite variable as it ranges from 0.04 and 0.08 in the SOS and QFS cohorts to 0.37 in Japanese subjects.

The present results are in accordance with data from other studies in which no difference has been found in the allelic frequencies between obese and nonobese subjects $(26,28,30)$. Only one study performed on obese and nonobese Japanese subjects (29) has reported a significant difference in allelic frequencies between the two groups. This mutation has also been reported to be more frequent in Japanese than in other ethnic

Table VIII. Age and Body Weight History in SOS Female Subjects According to Carrier Status

\begin{tabular}{|c|c|c|c|c|c|}
\hline \multirow[b]{2}{*}{ Variables } & \multicolumn{2}{|c|}{ Noncarriers } & \multicolumn{2}{|c|}{ With Trp64Arg mutation } & \multirow[b]{2}{*}{$P$ value } \\
\hline & $n$ & Mean \pm SD & $n$ & Mean \pm SD & \\
\hline Current age (yr) & 333 & $47.8 \pm 6.1$ & 52 & $47.8 \pm 6.0$ & 0.95 \\
\hline Body mass index $\left(\mathrm{kg} / \mathrm{m}^{2}\right)$ & 333 & $40.8 \pm 3.8$ & 52 & $41.2 \pm 4.2$ & 0.52 \\
\hline Waist circumference $(\mathrm{cm})$ & 333 & $119.1 \pm 9.7$ & 52 & $118.2 \pm 9.0$ & 0.50 \\
\hline Age of onset of weight problem (yr) & 329 & $20 \pm 10$ & 50 & $20 \pm 12$ & 0.94 \\
\hline Weight 2 yr ago (kg) & 330 & $102 \pm 14$ & 52 & $104 \pm 14$ & 0.62 \\
\hline Weight 1 yr ago (kg) & 331 & $105 \pm 13$ & 51 & $105 \pm 13$ & 0.77 \\
\hline Weight $1 / 2$ yr ago $(\mathrm{kg})$ & 331 & $108 \pm 12$ & 56 & $108 \pm 12$ & 0.86 \\
\hline Current weight (kg) & 333 & $110 \pm 13$ & 52 & $110 \pm 13$ & 0.94 \\
\hline Maximal weight (kg) & 333 & $114 \pm 13$ & 52 & $113 \pm 14$ & 0.86 \\
\hline \multicolumn{6}{|l|}{ Current weight minus weight } \\
\hline \multicolumn{6}{|l|}{ Maximal weight minus weight } \\
\hline at $20 \mathrm{yr}(\mathrm{kg})$ & 327 & $43 \pm 13$ & 52 & $41 \pm 17$ & 0.45 \\
\hline
\end{tabular}


QUINTILES OF WEIGHT GAINS IN SOS FEMALES

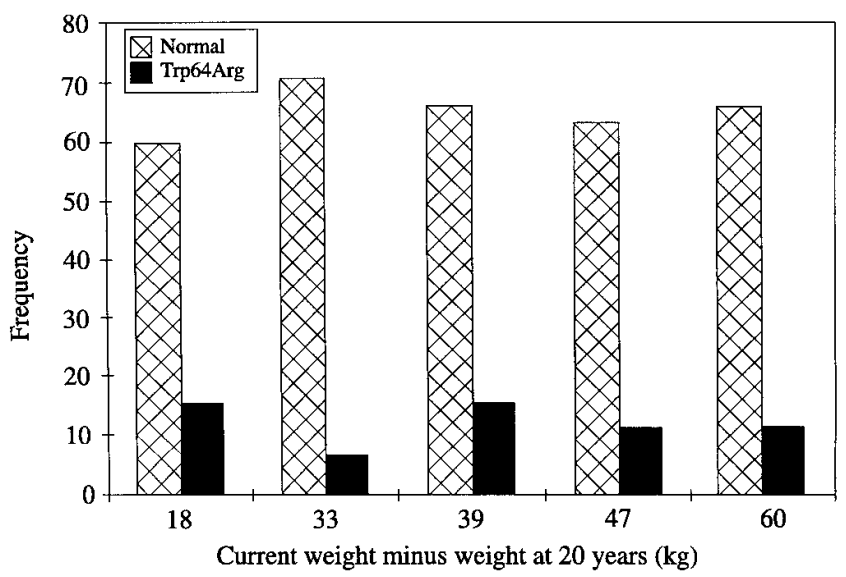

Figure 4. Current weight minus weight at $20 \mathrm{yr}$ by quintiles of the SOS cohort. No significant difference was found in the frequency of the Trp64Arg mutation among groups (chi-square $=8.00, P=0.43$ ), or between high $(60 \pm 8 \mathrm{~kg}) \mathrm{vs}$. low gainers $(18 \pm 10 \mathrm{~kg})$.

groups $(26,28,30)$. Then, one may ask, what is the significance of this Trp64Arg mutation? The hypothesis put forward in several papers (26-30) is that the Trp64Arg allele may play a role in predisposing patients to abdominal obesity, which may in turn lead to insulin resistance and an earlier onset of NIDDM. In addition, a low resting metabolic rate could lead to an accumulation of energy stores, weight gain, and therefore an obese state.

Based upon both association and linkage analyses, the present study did not reveal any significant difference between carriers and noncarriers for the Trp64Arg mutation for various obesity-related phenotypes in contrast to what has been previously reported by others (26-28). Moreover, the fact that abdominal visceral fat level is similar among Trp64Arg carriers and noncarriers does not support the hypothesis that this ADRB3 mutation leads to an excessive abdominal fat deposition, as already proposed by others (27). These results are concordant with those of a recent study performed on normal weight and obese nondiabetic subjects which revealed a lack of significant difference in anthropometric and metabolic variables as well as in visceral fat cell size and lipolytic response to noradrenaline or to the selective $\beta 3$ agonist CGP12177 between heterozygotes and homozygotes for the Trp64Arg mu-

Table IX. Sib-pair Linkage Analysis Results with the Trp64Arg ADRB3 Mutation in the QFS Cohort

\begin{tabular}{lccc}
\hline \multicolumn{1}{c}{ Variables } & $n$ pairs & $t$ value & $P$ value \\
\hline Body weight & 255 & -0.60 & 0.24 \\
Body mass index & 255 & -0.70 & 0.24 \\
Body fat & 213 & -0.09 & 0.46 \\
Fat mass & 213 & -0.26 & 0.39 \\
Fat free mass & 213 & -0.01 & 0.50 \\
Subcutaneous fat & 254 & -0.79 & 0.21 \\
Abdominal total fat & 144 & 0.24 & 0.60 \\
Abdominal visceral fat & 144 & 0.89 & 0.81 \\
Abdominal subcutaneous fat & 144 & 0.08 & 0.53 \\
Resting metabolic rate & 142 & -1.81 & 0.04
\end{tabular}

tation (49). The present study emphasizes the fact that this ADRB3 receptor mutation does not influence body fat and abdominal visceral fat levels. However, a recent knock-out gene study has shown that $\beta 3$ adrenoceptor deficient mice have moderately increased fat stores, suggesting that a total lack of ADRB3 activity may influence energy balance (50).

The base change predicts a replacement of tryptophan by arginine at position 64 (Trp64Arg), an amino acid located in the first of the three intracellular loops of the $\beta 3$ adrenoceptor $(26,51)$ which is thought to be important for the proper movement of the receptor to the adipose cell surface and also probably for its coupling to Gs proteins. However, species such as bovine, rat, and mouse have arginine instead of tryptophan at the same position of the $\beta 3$ adrenergic receptor (52). A computer-aided molecular modeling of the complex formed by the ADRB3 receptor and Gs proteins has shown that residues 134, $227 \rightarrow 234,276 \rightarrow 289,347$, and 361 of the $\beta 3$ adrenoceptor could be involved in the formation of this complex (53). Based on this simulation, the $\alpha$-helix structure of the first intracellular loop (Ala 61- Leu 68) does not appear to be critical. In this regard, deletion and substitution mutagenesis experiments performed on the $\beta 2$ adrenoceptor have highlighted that the third intracellular loop (i3) is the main domain involved in both ligand binding interactions and coupling of the receptor to Gs proteins (54). Similarly, it has recently been reviewed that amino acids residues responsible for the interaction between $\beta 3$ adrenoceptors and Gs proteins are located near the intracellular loop i3 and the C-terminal region, whereas the first intracellular loop of these receptors does not appear as an important determinant of the physiological responsiveness (55).

In summary, data obtained from two different cohorts, the QFS and the SOS, did not reveal any association between obesity-related phenotypes and the ADRB3 Trp64Arg mutation. The results suggest that the Trp64Arg mutation of the ADRB3 gene is unlikely to play a significant role in obesity, the accumulation of body fat over time, or abdominal visceral fat level.

\section{Acknowledgments}

The authors wish to thank Anne-Marie Bricault, Monique Chagnon, Michel Lacaille, and Caroline Noël for technical assistance. Thanks are also expressed to Dr. Germain Thériault, Guy Fournier, Lucie Allard for the data collection of the QFS, as well as to Suzanne Brulotte and Line Bargone from the Radiology Department at the Laval University Hospital Center, for the computed axial tomography assistance. We also acknowledge the contribution of Dr. Donny Strosberg from Institut Cochin de Génétique Moléculaire (Paris, France) to the early phase of this work. Lauren Lissner, Ph.D, is acknowledged for her work with the SOS controls. Thanks are also expressed to the members of the SOS Steering Committee: Lars Backman, Sven Dahlgren, Egon Jonsson, Sven Lindstedt, Lauren Lissner, Ingmar Näslund, Lars Olbe, Marianne Sullivan and Hans Wedel for their continued interest in the study. Furthermore, we express our gratitude to the staffs of the 480 primary health care centers in Sweden.

The authors acknowledge the financial support of the Medical Reseach Councils of Canada (PG-11811) for the Québec Family study, and of Sweden (05239) for the Swedish Obese Subjects. The SOS project was also supported by the Swedish Social Welfare Board, the Swedish Ministry of Education, Hoffmann-La Roche, and Volvo Research Foundation. Some of the results of this study were obtained with the program SAGE whose development was supported by the U.S. Public Health Service Research Grant from the National Center for Research Resources. 


\section{References}

1. Bouchard, C., and L. Pérusse. 1993. Genetics of obesity. Annu. Rev. Nutr. 13:337-354.

2. Ravussin, E., S. Lillioja, W.C. Knowler, L. Christin, D. Freymond, G.H. Abbott, V. Boyce, B.V. Howard, and C. Bogardus. 1988. Reduced rate of energy expenditure as a risk factor for body weight gain. N. Engl. J. Med. 318:467472.

3. Lafontan, M., and M. Berlan. 1993. Fat cell adrenergic receptors and the control of white and brown fat cell function. J. Lipid Res. 34:1057-1091.

4. Arch, J.R.S., and A.J. Kaumann. 1993. $\beta 3$ and atypical $\beta$-adrenoceptors. Med. Res. Rev. 13:663-729.

5. Emorine, L.J., S. Marullo, M.M. Briend-Sutren, G. Patey, K. Tate, C. Delavier-Klutchko, and D. Strosberg. 1989. Molecular characterization of the human $\beta 3$-adrenergic receptor. Science (Wash. DC). 245:1118-1121.

6. Granneman, J.G., K.N. Lahners, and A. Chaudry. 1993. Characterization of the human 33-adrenergic receptor gene. Mol. Pharmacol. 44:264-270.

7. Lelias, J.M., M. Kaghad, M. Rodriguez, P. Chalon, J. Bonnin, I. Dupré, B. Delpech, M. Bensaid, G. LeFur, P. Ferrara, and D. Caput. 1993. Molecular cloning of a human $\beta 3$-adrenergic receptor. FEBS Lett. 324:127-130.

8. Pietri-Rouxel, F., G. Lensen, A. Kapoor, M.F. Drumare, P. Archimbault, A.D. Strosberg, and B.S. Manning. 1995. Molecular cloning and pharmacological characterization of the bovine beta 3-adrenergic receptor. Eur. J. Biochem. 230:350-358

9. Granneman, J.G., K.N. Lahners, and A. Chaudry. 1991. Molecular cloning and expression of the rat $\beta 3$-adrenergic receptor. Mol. Pharmacol. 40:895-899.

10. Muzzin, P., J.P. Revelli, F. Kuhne, J.D. Gocayne, W.R. McCombie, J.C. Venter, J.P. Giacobino, and C.M. Fraser. 1991. An adipose tissue specific $\beta$-adrenergic receptor. Molecular cloning and down-regulation in obesity. J. Biol. Chem. 266:24053-24058.

11. Nahmias, C., N. Blin, J.M. Elalouf, M.G. Mattei, A.D. Strosberg, and L.J. Emorine. 1991. Molecular characterization of the mouse $\beta 3$-adrenergic receptor: relationship with the atypical adrenoceptor of adipocytes. EMBO J. 10: 3721-3727.

12. Zaagsma, J., and S.R. Nahorski. 1990. Is the adipocyte $\beta$-adrenoceptor a prototype for the recently cloned atypical $\beta 3$-adrenoceptor? Trends Pharmacol. Sci. 11:3-7.

13. Krief, S., F. Lönnqvist, S. Raimbault, B. Baude, A. Van Spronsen, P. Arner, A.D. Strosberg, D. Ricquier, and L.J. Emorine. 1993. Tissue distribution of $\beta 3$-adrenergic receptor mRNA in man. J. Clin. Invest. 91:344-349.

14. Emorine, L.J., N. Blin, and A.D. Strosberg. 1994. The human $\beta 3$-adrenoceptor: the search for a physiological function. Trends Pharmacol. Sci. 15:3-7.

15. Langin, D., M.P. Portillo, J.S. Saulnier-Blache, and M. Lafontan. 1991. Coexistence of three beta-adrenoceptor subtypes in white fat cells from various mammalian species. Eur. J. Pharmacol. 199:291-301.

16. Bousquet-Mélou, A., J. Galitzky, M. Lafontan, and M. Berlan. 1995. Control of lipolysis in intra-abdominal fat cells of nonhuman primates: comparison with humans. J. Lipid Res. 36:451-461.

17. Tavernier, G., P. Barbe, J. Galitzky, M. Berlan, D. Caput, M. Lafontan, and D. Langin. 1996. Expression of $\beta 3$-adrenoceptors with low lipolytic action in human subcutaneous white adipocytes. J. Lipid Res. 37:87-97.

18. Rosenbaum, M., C.C. Malbon, J. Hirsch, and R.L. Leibel. 1993. Lack of $\beta 3$-adrenergic effect on lipolysis in human subcutaneous adipose tissue. J. Clin. Endocrinol. Metab. 77:352-355.

19. Lönnqvist, F., S. Krief, A.D. Strosberg, B. Nyberg, L.J. Emorine, and P. Arner. 1993. Evidence of a functional $\beta 3$-adrenoceptor in man. Br. J. Pharmacol. 110:929-936.

20. Lönnqvist, F., A. Thörne, K. Nilsell, J. Hoffstedt, and P. Arner. 1995. A pathogenic role of visceral fat $\beta 3$-adrenoceptors in obesity. J. Clin. Invest. 95 : 1109-1116.

21. Van Liefde, I., A. Van Ermen, and G. Vauquelin. 1994. No functional atypical $\beta$-adrenergic receptors in human omental adipocytes. Life Sci. 54:209-214.

22. Mauriège, P., A. Marette, C. Atgié, C. Bouchard, G. Thériault, L.J. Bukowiecki, P. Marceau, S. Biron, A. Nadeau, and J.P. Després. 1995. Regional variation in adipose tissue metabolism of severely obese women. J. Lipid Res. 36:672-684.

23. Enocksson, S., M. Shimizu, F. Lönnqvist, J. Nordenström, and P. Arner. 1995. Demonstration of an in vivo functional $\beta 3$-adrenoceptor in man. J. Clin. Invest. 95:2239-2245.

24. Barbe, P., L. Millet, J. Galitzky, M. Lafontan, and M. Berlan. 1996. Insitu assessment of the role of the $\beta 1-, \beta 2$ - and $\beta 3$-adrenoceptors in the control of lipolysis and nutritive blood-flow in human subcutaneous adipose-tissue. $\mathrm{Br}$. J. Pharmacol. 117:907-913.

25. Hoffstedt, J., M. Shimizu, S. Sjöstedt, and F. Lönnqvist. 1995. Determination of $\beta 3$-adrenoceptor mediated lipolysis in human fat cells. Obes. Res. 3:447-457.

26. Walston, J., K.D. Silver, C. Bogardus, W.C. Knowler, F.S. Celi, S. Austin, B. Manning, A.D. Strosberg, M.P. Stern, N. Raben et al. 1995. Time of onset of non-insulin-dependent diabetes mellitus and genetic variation in the $\beta 3$ adrenergic receptor gene. N. Engl. J. Med. 333:343-347.

27. Widén, E., M. Lehto, T. Kanninen, J. Walston, A.R. Shuldiner, and L.C. Groop. 1995. Association of a polymorphism in the $\beta 3$-adrenergic receptor gene with features of the insulin resistance syndrome in Finns. N. Engl. J. Med.
333:348-351.

28. Clément, K., C. Vaisse, B. St-J Manning, A. Basdevant, B. Guy-Grand, J. Ruiz, K.D. Silver, A.R. Shuldiner, P. Froguel, and A.D. Strosberg. 1995. Genetic variation in the $\beta 3$-adrenergic receptor and an increased capacity to gain weight in patients with morbid obesity. N. Engl. J. Med. 333:352-354.

29. Kadowaki, H., K. Yasuda, K. Iwamoto, S. Otabe, K. Shimokawa, K. Silver, J. Walston, H. Yoshinaga, K. Kosaka, N. Yamada et al. 1995. A mutation in the $\beta 3$-adrenergic receptor gene is associated with obesity and hyperinsulinemia in Japanese subjects. Biochem. Biophys. Res. Commun. 215:555-560.

30. Yoshida, T., N. Sakane, T. Umekawa, M. Sakai, T. Takashaki, and M. Kondo. 1995. Mutation of $\beta 3$-adrenergic-receptor gene and response to treatment of obesity. Lancet. 346:1433-1434.

31. Bouchard, C. 1996. Genetic epidemiology, association, and sib-pair linkage: Results from the Québec Family Study. In Molecular and Genetic Aspects of Obesity. Vol. 5. G.A. Bray and D.H. Ryan, editors. Louisiana State University Press, Pennington Center Nutrition Series, Baton Rouge, LA. 470-481.

32. Sjöström, L., B. Larsson, L. Backman, C. Bengtsson, C. Bouchard, S. Dahlgren, P. Hallgren, E. Jonsson, J. Karlsson, L. Lapidus et al. 1992. Swedish obese subjects (SOS): Recruitment for an intervention study and a selected description of the obese state. Int. J. Obes. 16:465-479.

33. Lissner, L., L. Sjöström, C. Bengtsson, C. Bouchard, and B. Larsson. 1994. The natural history of obesity in an obese population and associations with metabolic aberrations. Int. J. Obes. 18:441-447.

34. Behnke, A.R., and J.H. Wilmore. 1974. Evaluation and regulation of body build and composition. Prentice Hall, Englewood Cliffs, NJ. 20-37.

35. Meneely, G.R., and N.L. Kaltreider. 1949. The volume of the lung determined by helium dilution: description of the method and comparison with other procedures. J. Clin. Invest. 28:129-139.

36. Siri, W.E. 1956. The gross composition of the body. In Advances in biological and medical physics. Vol 4. J.H. Lawrence, and C.A. Tobias, editors. Academic Press, NY. 239-280.

37. The Airlie (VA) consensus conference. 1988. In Anthropometric Standardization Reference Manual. T.G. Lohman, A.F. Roche, and R. Martorell, editors. Human Kinetics Publishers, Champaign, IL. 39-80.

38. Ferland, M., J.P. Després, A. Tremblay, S. Pinault, A. Nadeau, S. Moorjani, P.J. Lupien, G. Thériault, and C. Bouchard. 1989. Assessment of adipose tissue distribution by computed axial tomography in obese women: Association with body density and anthropometric measurements. Br. J. Nutr. 61:139-148.

39. Oppert, J.M., M.C. Vohl, M. Chagnon, F.T. Dionne, A.M. CassardDoulcier, D. Ricquier, L. Pérusse, and C. Bouchard. 1994. DNA polymorphism in the uncoupling protein (UCP) gene and human body fat. Int. J. Obes. 18:526-531.

40. Weir, J.B. 1949. New methods for calculating metabolic rate with special reference to protein metabolism. J. Physiol. (Lond). 109:1-9.

41. Oppert, J.M., A. Nadeau, A. Tremblay, J-P. Després, G. Thériault, O. Dériaz, and C. Bouchard. 1995. Plasma glucose, insulin and glucagon before and after long term overfeeding in identical twins. Metab. Clin. Exp. 44:96-105.

42. Richterich, R., and H. Dauwalder. 1971. Zur Bestimmung der Plasmaglukose-Konzentration mit der Hexokinase-Glucose-6-Phosphat-Dehydrogenase Methode. Schweiz. Med. Wochenschr. 101:615-618.

43. Desbuquois, B., and G.D. Aurbach. 1971. Use of polyethylene glycol to separate free and antibody-bound peptide hormones in radioimmunoassays. $J$. Clin. Endocrinol. Metab. 37:732-738.

44. Nilsson, K. 1976. Establishment of permanent human lymphoblastoid cell lines in vitro. In In Vitro Methods in Cell-Mediated and Tumor Immunity. B.R. Bloom, and J.R. David, editors. Academic Press, New York. 713-735.

45. Haseman, J.K., and R.C. Elston. 1972. The investigation of linkage between a quantitative trait and a marker locus. Behav. Genet. 2:3-19.

46. Amos, C.I., R.C. Elston, A.F. Wilson, and J.E. Bailey-Wilson. 1989. A more powerful test of linkage for quantitative traits. Genet. Epidemiol. 6:435-439.

47. Statistical Analysis for Genetic Epidemiology, release 2.1 (SAGE). 1992. Computer program package available from the Department of Biometry and Genetics, LSU Medical Center, New Orleans.

48. Benson, D.A., M. Boguski, D.J. Lipman, and J. Ostell. 1994. GenBank. Nucl. Acid Res. 22:3441-3444.

49. Li, L.S., F. Lönnqvist, H. Luthman, and P. Arner. 1996. Phenotypic characterization of the Trp64Arg polymorphism in the beta3-adrenergic receptor gene in normal weight and obese subjects. Diabetologia. 39:857-860.

50. Susulic, V.S., R.C. Frederich, J. Lawitts, E. Tozzo, B.B. Kahn, M.E. Harper, J. Himms-Hagen, J.S. Flier, and B.B. Lowell. 1995. Targeted disruption of the B3-adrenergic receptor gene. J. Biol. Chem. 270:29483-29492.

51. Emorine, L., and D. Strosberg. 1993. Structure et fonction du récepteur B3-adrénergique. Med. Sci. 9:1228-1235.

52. Ezzel, C. 1995. Research in a focus; fat times for obesity research: Tons of new information, but how does it all fit together? J NIH Res. 7:39-43.

53. Mahmoudian, M. 1994. The complex of human Gs protein with the beta3 adrenergic receptor: A computer-aided molecular modeling study. $J$. Mol. Graphics. 12:22-28.

54. Liggett, S. 1995. Functional properties of human $\beta 2$-adrenergic receptor polymorphism. NIPS. 10:265-273.

55. Strosberg, A.D. 1995. Adrenergic, dopaminergic and histaminergic drugs: Structure, function, and regulation of the three $\beta$-Adrenergic receptors. Obes. Res. 3(suppl.):501S-505S. 